\title{
Neutralization of a Cytopathogenic Bovine Orphan Virus in Tissue Culture by Heat Stable Francis Type Inhibitors in Normal Animal Sera
}

\author{
By G. S. TURNER, A. KIPPS, A. POLSON \\ AND THE LATE M. VAN DEN ENDE \\ The Council for Scientific and Industrial Research and University of Cape \\ Town's Virus Research Unit, University of Cape Town, South Africa
}

(Received 14, March 1961)

\begin{abstract}
SUMMARY
A heat stable inhibitor present in the serum of normal animals was found to neutralize the infectivity of a cytopathogenic bovine orphan (CBO) virus. Its distribution and some physical, chemical and biological properties were examined. These properties suggest that the inhibitor for the virus infectivity is similar to, but not identical with Francis type inhibitors in normal animal sera.
\end{abstract}

\section{INTRODUCTION}

Many non-specific inhibitors of virus activity have been described in the tissues, body fluids or sera of normal animals. These inhibitors have been differentiated principally by the viruses which they affect, by their sensitivity to heat, enzymes or chemical reagents and by their ability to inhibit haemagglutination or to neutralize infectivity. Only a few have been obtained in pure or almost pure state. During an investigation of the properties of the Van den Ende strain of a cytopathogenic bovine orphan (CBO) virus (Kipps, Turner \& Polson, 1961), it was noticed that the sera of normal animals of several species caused striking inactivation of the virus, shown by a decrease of the infectivity in chick embryos or the plaque-forming capacity in chick embryo tissue cultures. Further study revealed that the inactivating agent was relatively resistant to heat and resembled in many respects the heat stable serum components inhibiting haemagglutination by myxoviruses collectively known as the Francis, or $\alpha$, inhibitor. The present paper describes some of the properties of the CBO virus inhibitor and its relationship with other known inhibitors.

\section{METHODS}

The viruses, the preparation of antisera, the propagation and titration of this CBO virus and the methods of neutralization are described in the preceding paper (Kipps et al. 1961).

Normal sera. Sera were obtained from clotted blood and heated to $56^{\circ}$ for $30 \mathrm{~min}$. to inactivate heat labile inhibitors. When serum samples were not used immediately they were stored at $-20^{\circ}$.

Mucoproteins. Samples of meconium and of urinary and sheep salivary mucoprotein were obtained from the Walter and Eliza Hall Institute, Melbourne, 
Australia. Egg white inhibitor was prepared according to the method of Sugihara, McDonell, Knight \& Feeney (1955). Ovomucin from allantoic fluid was concentrated by dialysis of the fluid against $\mathrm{pH} 4 \cdot 3$ buffer at $4^{\circ}$. The resultant precipitate was redissolved in a minimal volume of $0.066 \mathrm{M}$-phosphate buffer ( $\mathrm{pH} \mathrm{8 \cdot 2)}$.

Haemagglutination inhibition (HI). Inhibition of haemagglutination was estimatedby standard methods using 4 agglutinating doses (AD) of heated influenza $B$ virus (Lee) as indicator.

Electrophoresis. Two methods were used for the separation of inhibitor in normal rabbit sera. One made use of the method of Polson (1952) allowing the simultaneous analysis of two solutions, and the other the technique of Svensson \& Valmet (1955) in a vertical column of modified cellulose (Peterson \& Sober, 1956).

Preparation of materials. Crystalline trypsin (Armour) was dissolved in phosphate buffer ( $\mathrm{pH} \mathrm{8.2)} \mathrm{immediately} \mathrm{before} \mathrm{use.} \mathrm{Commercial} \mathrm{receptor-destroying} \mathrm{enzyme}$ (RDE, Phillips Roxane) was reconstituted according to the maker's instructions. Solutions of potassium periodate of various molarities were freshly prepared in distilled water. Zymosan and properdin-free sera were prepared by the method of Pillemer et al. (1954).

Buffer solutions. Dilute acetate buffer ( $\mathrm{pH} \mathrm{5 \cdot 2)}$ contained $2 \mathrm{~g} . \mathrm{NaOH}$ and $4 \mathrm{ml}$. glacial acetic acid/l. Phosphate buffers were prepared by mixing $0.066 \mathrm{M}-\mathrm{Na}_{2} \mathrm{HPO}_{4}$ and $0.066 \mathrm{M}-\mathrm{KH}_{2} \mathrm{PO}_{4}$ to give the required $\mathrm{pH}$ value; $\mathrm{pH} 4.3$ buffer contained $2.5 \mathrm{~g}$. citric acid and $2 \cdot 5 \mathrm{~g} . \mathrm{Na}_{2} \mathrm{HPO}_{4} / \mathrm{l}$.

\section{RESULTS}

Neutralization of $\mathrm{CBO}$ virus by normal sera

The apparent neutralizing titre of the serum depends on the virus concentration (Table 1), but with 60-100 plaque-forming units (p.f.u.) most rabbit sera diluted $10^{-3}$ caused a $50 \%$ reduction in the plaque count. For this reason normal rabbit

\section{Table 1. Neutralization of $\mathrm{CBO}$ virus by normal rabbit serum}

\begin{tabular}{crrrrr}
$\begin{array}{c}\text { Virus } \\
\text { dilution }\end{array}$ & $\overbrace{10^{-1}}^{\text {Serum dilutions }}$ & \multicolumn{1}{c}{$0^{-2}$} & $10^{-3}$ & $10^{-4}$ & $\begin{array}{r}\text { Control } \\
\text { without } \\
\text { serum }\end{array}$ \\
$10^{-2}$ & 65 & $\mathrm{c}$ & $\mathrm{c}$ & $\mathrm{c}$ & $\mathrm{c}$ \\
$10^{-3}$ & 15 & $\mathrm{sc}$ & $\mathrm{sc}$ & $\mathrm{c}$ & $\mathrm{c}$ \\
$10^{-4}$ & $\mathrm{3}$ & 42 & 85 & sc & sc \\
$10^{-5}$ & 1 & 11 & 34 & 60 & 60 \\
$10^{-6}$ & 0 & 0 & 5 & 12 & 13
\end{tabular}

Numbers $=$ average plaque count from duplicate plates; c, confluent plaques; sc, semi-confluent plaques.

serum was used for most of the experiments. Normal rabbit serum was also tested for its neutralizing activity in chick embryos, mice or monkey kidney tissue cultures against the viruses of influenza (PR 8), Newcastle disease, poliomyelitis (Mahoney), rabies (Flury),.Rift Valley fever (pantropic and neurotropic), African horse sickness, yellow fever, West Nile and Semliki Forest viruses. In no instance was significant inhibition of infectivity demonstrated. The concentration of inhibitor in the heated sera of a variety of normal animals was determined against 60 p.f.u. of CBO virus. In order to allow as far as possible for individual variations, pooled sera from a 
group of each species were used. The neutralizing effect of human, rabbit and guineapig sera was high, that of rat, bovine, horse and ferret sera somewhat lower, while fowl and mouse sera had little if any activity (Fig. 1).

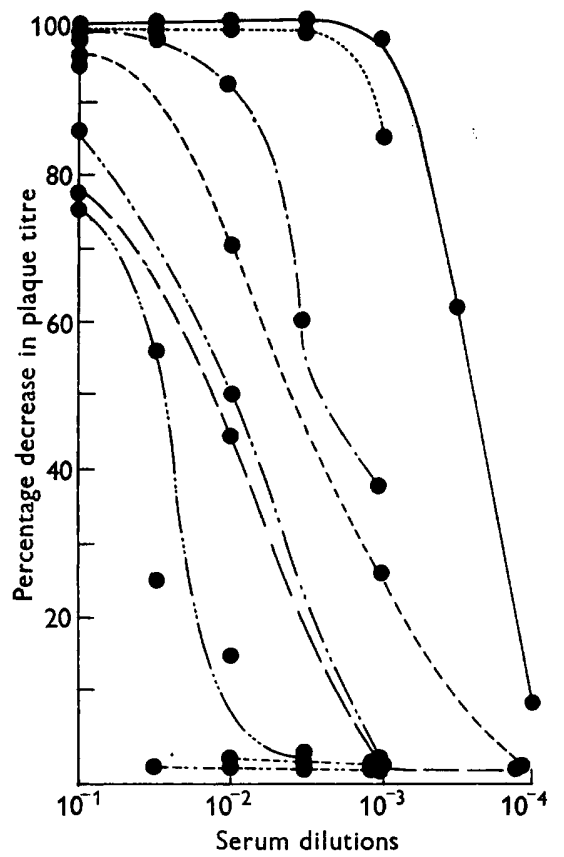

Fig. 1. The inhibitory effect of various normal animal sera against 60 p.f.u. of virus.

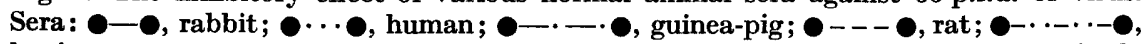
bovine; $-\longrightarrow$, horse; $-\ldots \ldots . .$. , ferret; $-\cdots \cdot-\cdot$, mouse;

Relation between inactivation of $\mathrm{CBO}$ virus and haemagglutination inhibition

The neutralizing powers of the pooled sera against $\mathrm{CBO}$ virus were compared with their potency as inhibitors of haemagglutination by heated influenza $B$ virus (Lee) (Table 2). Although there was some parallelism between the neutralizing and HI

Table 2. Haemagglutination-inhibition and $\mathrm{CBO}$ virus neutralization by normal animal sera

\begin{tabular}{|c|c|c|}
\hline $\begin{array}{c}\text { Normal* } \\
\text { animal sera }\end{array}$ & $\begin{array}{l}\text { Reciprocal of } \\
\text { dilution of serum } \\
\text { causing inhibition of } \\
\text { haemagglutination } \\
\text { by } 4 \text { AD Lee } B \\
\text { indicator virus }\end{array}$ & $\begin{array}{c}\text { Reciprocal of } \\
\text { dilution of serum } \\
\text { causing } 50 \% \\
\text { reduction of plaque } \\
\text { count with } 60 \text { p.f.u. } \\
\text { CBO virus }\end{array}$ \\
\hline Mouse & 10 & $<10$ \\
\hline Ferret & 2580 & $10-100$ \\
\hline Fowl & 80 & $<10$ \\
\hline Guinea-pig & 320 & $100-1000$ \\
\hline Human & 1280 & $>1000$ \\
\hline Horse & 5 & $100-1000$ \\
\hline Bovine & 5 & 100 \\
\hline Rabbit & 80 & $>1000$ \\
\hline
\end{tabular}


powers of the different sera (in the cases of human and mouse sera for example), ferret serum was relatively more effective as an inhibitor of haemagglutination and rabbit serum more effective as a neutralizer of $\mathrm{CBO}$ virus. Mucoproteins from sources other than serum, though highly active as inhibitors of haemagglutination, failed to neutralize CBO virus (Table 3).

Table 3. Haemagglutination-inhibition and $\mathrm{CBO}$ virus neutralization by mucoproteins

\begin{tabular}{|c|c|c|c|}
\hline Mucoprotein from & Concentration & $\begin{array}{l}\text { Dilution causing } \\
\text { inhibition of } \\
\text { haemagglutination } \\
\text { by } 4 \text { AD Lee B } \\
\text { indicator virus }\end{array}$ & $\begin{array}{c}\text { Inhibition of } \\
60 \text { p.f.u. CBO } \\
\text { virus by } \\
\text { undiluted } \\
\text { mucoprotein }\end{array}$ \\
\hline Meconium & $10 \mathrm{mg} . / \mathrm{ml}$ & $10^{-4}$ & nil \\
\hline Sheep salivary mucin & $1 \mathrm{mg} \cdot / \mathrm{ml}$ & $10^{-6}$ & nil \\
\hline Urinary mucin & $1 \mathrm{mg} . / \mathrm{ml}$ & $10^{-4}$ & nil \\
\hline Egg white in saline & $20 \%(v / v)^{*}$ & $10^{-1.8}$ & nil \\
\hline Allantoic fluid & $20 \times$ conc. $*$ & $10^{-1 \cdot 8}$ & nil \\
\hline
\end{tabular}

\section{Concentration of the $\mathrm{CBO}$ inhibitor from rabhit serum}

The precipitates formed by bringing the normal serum to half saturation with ammonium sulphate contained much of the virus neutralizing activity. Dialysis overnight against acetate buffer $\mathrm{pH} 5.2$ was as effective. Little activity remained in the supernatant fluid and most of it could be recovered from the precipitate by extraction with phosphate buffer of $\mathrm{pH} \mathrm{8.4} \mathrm{(Table} \mathrm{4).} \mathrm{The} \mathrm{sera} \mathrm{of} \mathrm{fowls} \mathrm{which} \mathrm{had}$ been immunized against CBO virus contained neutralizing antibody which, however, was not precipitated at $\mathrm{pH} 5 \cdot 2$, the activity remaining in the supernatant fluid (Table 5). The agent was not sedimented by centrifugation of the serum at 33,000 rev./min. for $3 \mathrm{hr}$. in the no. 40 rotor of a Spinco Model L centrifuge, nor was it present in the lipid layer which separated during this treatment. When the serum was shaken with ether and the mixture centrifuged the agent remained in the aqueous phase.

Table 4. Plaque count in presence of serum fractions diluted 1/10

\begin{tabular}{lc}
\multicolumn{1}{c}{ Sample } & Plaque count \\
(1)* Globulins & $2.0 \times 10^{3}$ \\
(2) Albumin & $1.1 \times 10^{6}$ \\
(3) Virus alone & $4.8 \times 10^{6}$ \\
(4) pH 5.2 ppt & $2.0 \times 10^{4}$ \\
(5) pH 5.2 SNF & $5.0 \times 10^{7}$ \\
(6) Virus alone & $4.0 \times 10^{7}$
\end{tabular}

* (1) Precipitate at half saturation with $\left(\mathrm{NH}_{4}\right)_{2} \mathrm{SO}_{4}$ redissolved in distilled water and dialysed against saline.

(2) Supernatant fluid from (1) dialysed to remove $\left(\mathrm{NH}_{4}\right)_{2} \mathrm{SO}_{4}$.

(4) Serum dialysed overnight at $4^{\circ}$ against a large volume of dilute acetate buffer (pH 5.2). The precipitate redissolved in phosphate buffer (pH 8.4) dialysed against buffered saline and brought to the volume of the original serum.

(5) The supernatant fluid (SNF) from (4) dialysed against buffered saline. 


\section{Table 5. Fractionation of $C B O$ neutralizing agent in forvl immune} serum by precipitation at $\mathrm{pH} \mathbf{5} \cdot \mathbf{2}$

The sera (normal or immune) were dialysed at $4^{\circ}$ overnight against acetate buffer (pH 5.2). The precipitates were redissolved in phosphate buffer (pH 8.4). The supernatant fluids and the redissolved precipitates were dialysed against buffered saline and, after correction of their volumes to those of the original sera, were titrated against CBO virus in agar suspension cultures of chick embryo cells.

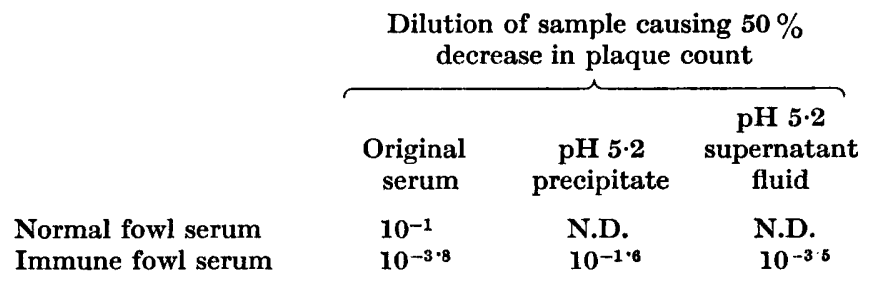

N.D. = not done.

\section{Electrophoresis of the $\mathrm{CBO}$ inhibitor}

Normal rabbit serum which had been heated at $56^{\circ}$ for $30 \mathrm{~min}$. was submitted to electrophoresis in phosphate buffer ( $\mathrm{pH} 8 \cdot 2$, ionic strength $0 \cdot 1$ ). The apparatus (Polson, 1952) allowed simultaneous analysis of two solutions and convenient sampling after electrophoresis. The progress of separation (descending boundaries only) was observed by the Lamm scale method. After electrophoresis at $4.5 \mathrm{~V} . / \mathrm{cm}$. and $1.5^{\circ}$ for about $4 \mathrm{hr}$., successive layers were removed (Polson, Joubert \& Haig, 1946), serially diluted and tested for neutralizing activity against $C B O$ virus on agar suspension cultures of chick embryo cells (Cooper, 1955). Photographs of the scale taken before sampling and after removal of each fraction enabled the electrophoresis diagram and the relation thereto of the samples to be accurately determined. The electrophoresis diagram of the serum (Fig. 2) shows the position of the samples tested and relative neutralizing power. Most of the inhibitor migrated to a position between the albumin and $\alpha$ globulin.

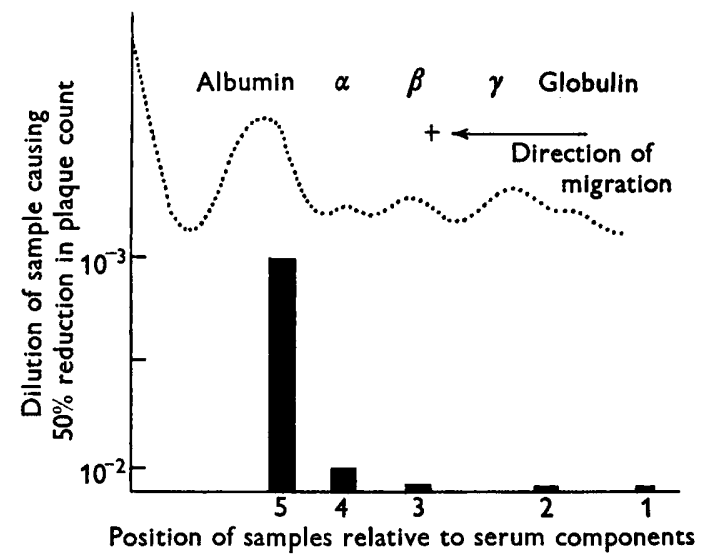

Fig. 2. Electrophoresis of normal rabbit serum at pH 8.2, $4.5 \mathrm{~V} . / \mathrm{cm}$. and $1.5^{\circ}$ for $4 \mathrm{hr}$. showing the position of the virus inhibitor. 
Partially purified CBO inhibitor was also submitted to zone electrophoresis at $\mathrm{pH} 8 \cdot 6$. The fraction of normal rabbit serum precipitated at $\mathrm{pH} 5 \cdot 2$ was redissolved in phosphate buffer ( $\mathrm{pH} 8 \cdot 6$ ) and centrifuged at $12,000 \mathrm{rev} . / \mathrm{min}$. for $15 \mathrm{~min}$. The sediment and a small lipoid layer which collected at the surface were discarded. The solution, which was faintly blue, was dialysed against borate buffer $(\mathrm{pH} 8 \cdot 6)$ and submitted to electrophoresis at $46-47 \mathrm{~mA}$. for $19 \mathrm{hr}$. in a vertical column of modified cellulose (Peterson \& Sober, 1956) in the apparatus of Svensson \& Valmet (1955) adapted to permit continuous recirculation of buffer through the electrode vessels. Buffer streams leaving the anode and cathode compartments were mixed and returned to an overhead supply vessel by a small pump. The current through the apparatus and the $\mathrm{pK}$ value of the buffer then remained constant throughout a run. After electrophoresis the column contents were displaced by buffer and collected fractionally. The fractions were tested for ultraviolet absorption at $275 \mathrm{~m} \mu$, neutralizing activity against $\mathrm{CBO}$ virus and haemagglutination inhibition against heated Lee $\mathbf{B}$ virus (Fig. 3).

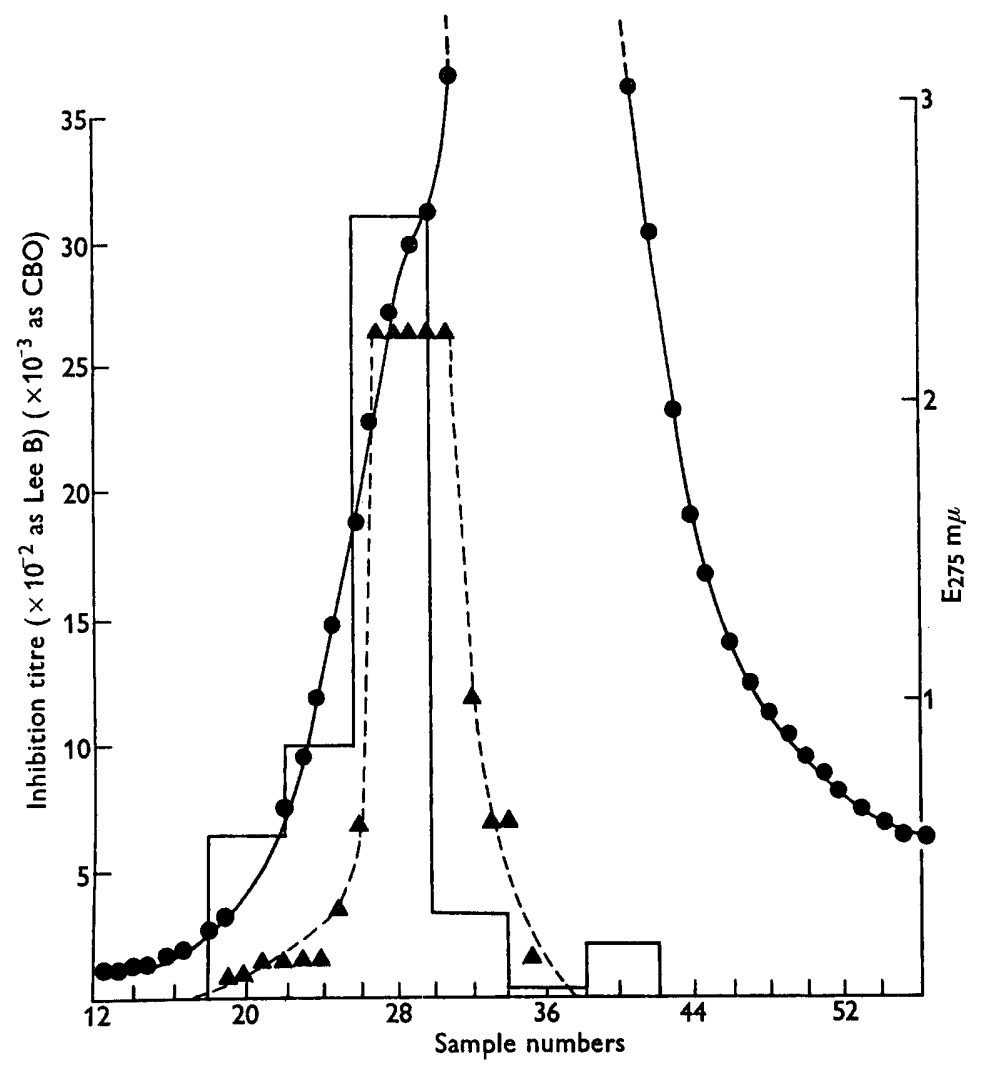

Fig. 3. Column electrophoresis of partially purified inhibitor. - - Light absorption; $\triangle-\triangle$, inhibition of $4 \mathrm{AD}$ Lee $\mathrm{B}$ indicator virus; $\Pi, 50 \%$ inhibition of $\mathrm{CBO}$ virus.

The effect of heat on the CBO inhibitor in normal rabbit and human sera

The neutralizing power of normal rabbit serum against $\mathrm{CBO}$ virus was not significantly decreased by heating for $1 \mathrm{hr}$. at $56^{\circ}$. Portions of normal rabbit serum diluted 
$\mathbf{1} / \mathbf{5}$ in saline were heated in a water-bath for $30 \mathrm{~min}$. at various temperatures above $56^{\circ}$ and assayed for haemagglutination inhibition (HI) of Lee $\mathrm{B}$ virus and neutralization of $\mathrm{CBO}$ virus. In the temperature range $65^{\circ}-100^{\circ}$ the neutralizing activity was more sensitive to heat than the HI activity; both were, however, still detectable in the sample heated at $100^{\circ}$ for $30 \mathrm{~min}$. (Fig. 4).

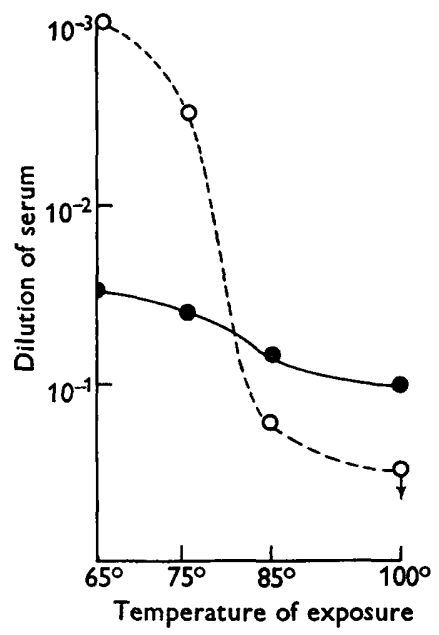

Fig. 4. The effect of heat on the inhibitors in normal rabbit serum to CBO virus and influenza (Lee B) virus. $O_{---}$, Serum dilutions causing $50 \%$ decrease in plaque count of $\mathrm{CBO}$ virus ; - - , serum dilution causing inhibition of $4 \mathrm{AD}$ of influenza virus (Lee $\mathrm{B}$ ).

Zhdanov, Hamburg \& Svet-Moldavsky (1959) showed that the HI activity of normal human serum towards certain strains of Type $\mathbf{A}_{2}$ influenza virus was greatly increased by heating at $85^{\circ}$. A sample of normal human serum heated at this temperature for $15 \mathrm{~min}$. was found to have lost most of its neutralizing activity against $\mathrm{CBO}$ virus whereas its $\mathrm{HI}$ titre when tested against influenza virus $\mathrm{A}_{2} /$ Cape Town/59 had increased from 60 to more than 2560.

The effect of receptor-destroying enzyme (RDE) and active influenza $B$ virus (Lee) on the CBO inhibitor in normal rabbit serum

One ml. portions of normal rabbit serum were treated either with $5 \mathrm{ml}$. RDE solution or $5 \mathrm{ml}$. saline, incubated for $18 \mathrm{hr}$. at $37^{\circ}$, heated for $1 \mathrm{hr}$. at $56^{\circ}$ and assayed for neutralization of $\mathrm{CBO}$ virus and $\mathrm{HI}$ of influenza $\mathrm{B}$ indicator. Similarly, $1 \mathrm{ml}$. amounts of normal rabbit serum were treated with $1 \mathrm{ml}$. volumes of active influenza B virus (Lee) purified according to Burnet (1948) and containing 400 AD. The mixtures were incubated at $37^{\circ}$ for $18 \mathrm{hr}$., heated to $65^{\circ}$ for $30 \mathrm{~min}$. and diluted for assay. Controls were prepared in the same way except that active Lee $B$ virus was replaced by heat inactivated influenza $B$ virus or by tap water. The CBO inhibitor resembled the haemagglutination inhibitor in normal rabbit serum in its sensitivity to the enzymes in RDE and active influenza $B$ virus (Table 6).

\section{The effect of trypsin on the $\mathrm{CBO}$ inhibitor in normal rabbit serum}

One ml. portions of normal rabbit serum were treated either with $1 \mathrm{ml}$. of buffer (pH 8.2) containing 8.0 mg. crystalline trypsin or $1 \mathrm{ml}$. buffer without trypsin. The mixture was incubated at $37^{\circ}$ for $20 \mathrm{hr}$., treated with $3 \mathrm{ml}$. saline containing $12 \mathrm{mg}$. 
Table 6. The effect of $R D E$ and active Lee $B$ influenza virus on the inhibitor in normal rabbit serum

For details see text.

$\begin{array}{lrr} & \overbrace{}^{\text {CBO }} & \begin{array}{c}\text { Heated } \\ \text { Lee B } \\ \text { virus }\end{array} \\ \begin{array}{l}\text { Normal rabbit serum } \\ \text { treated with }\end{array} & \begin{array}{c}\text { \% decrease of } \\ \text { of samples of } \\ \text { serum against }\end{array} \\ \text { (1) Nil } & 0 & 0 \\ \text { (2) Saline } & 2 & 5 \\ \text { (3) RDE } & 85 & 94 \\ \text { (4) Heated Lee B virus } & 4 & 25 \\ \text { (5) Water } & 4 & 25 \\ \text { (6) Active Lee B virus } & 85 & 94\end{array}$

soya-bean trypsin inhibitor, and assayed for $\mathrm{CBO}$ virus neutralizing activity and $\mathrm{HI}$ of influenza $B$ (Lee) indicator virus. The enzyme caused considerable reduction in both types of inhibitory activity (Fig. 5).

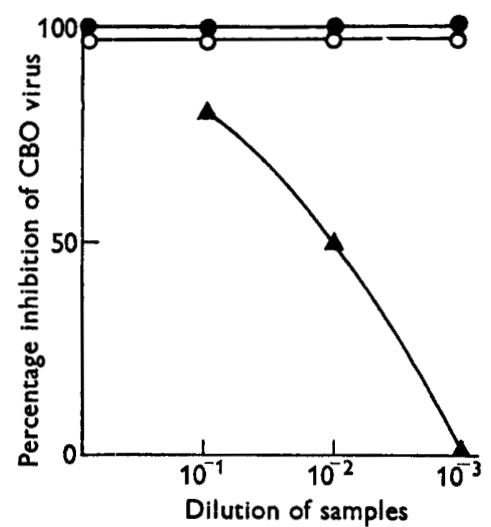

Fig. 5. Effect of trypsin on the inhibitor to $\mathrm{CBO}$ virus in normal rabbit serum. :-: control samples without trypsin (HI titre with heated Lee B virus $=160$ ). $\Delta-\Delta$, trypsintreated sample (HI titre with heated Lee $B$ virus $<5$ ).

\section{The effect of potassium periodate}

Portions of normal rabbit serum were mixed with equal volumes of either saline or of one of a series of dilutions of a freshly prepared solution of potassium periodate. The mixtures were held at $37^{\circ}$ for $1 \mathrm{hr}$., treated with glycerol $(0.02 \mathrm{ml}$.) to destroy excess reagent and assayed for their effect on $\mathrm{CBO}$ and Lee $\mathrm{B}$ viruses. Both types of activity were about equally sensitive to periodate treatment (Fig. 6).

\section{Differentiation of the $\mathrm{CBO}$ inhibitor from properdin}

Treatment of freshly drawn normal rabbit serum with a concentration of zymosan which had proved sufficient to remove the $\mathrm{C} 3$ component of complement in normal rabbit serum had no effect upon its neutralizing activity against CBO virus. Normal 


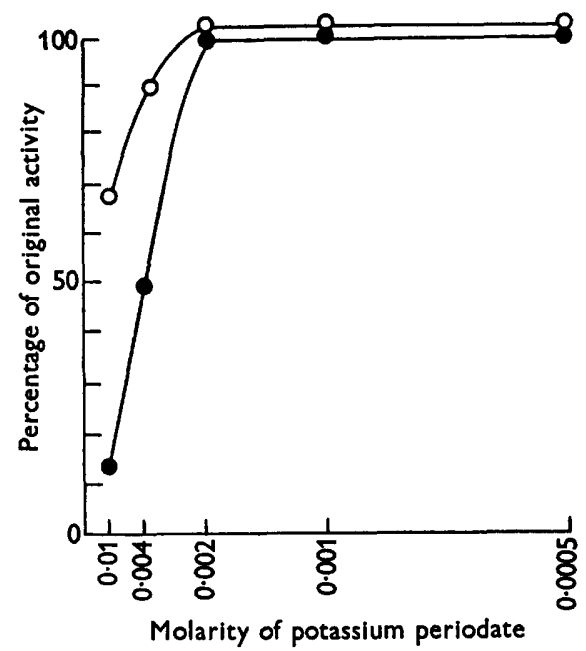

Fig. 6. Effect of periodate on CBO and Lee $B$ inhibitors in normal rabbit serum. $O-O$, against heated Lee $\mathrm{B}$ virus; - -0 , against $\mathrm{CBO}$ virus.

human serum containing $5 \cdot 7$ units properdin/ml. and a sample of RP (Pillemer et al. 1954) prepared from it by removing all detectable properdin with zymosan, gave identical results in the neutralization test against $\mathrm{CBO}$ virus.

\section{The effect of RDE and active influenza $B$ virus (Lee) on the virus + inhibitor complex}

During the experiments recorded above it was noticed that RDE and active influenza $B$ virus (Lee) were capable of liberating active $\mathrm{CBO}$ virus from the inactive complex which it forms with the inhibitory agent. A mixture of undiluted normal rabbit serum and suitably diluted $\mathrm{CBO}$ virus was allowed to stand at room temperature for $1 \mathrm{hr}$. and divided into six portions. To one portion was added $1 \mathrm{ml}$. of active influenza $B$ virus (Lee), to the second heat-inactivated influenza $B$ virus (Lee) $\left(56^{\circ}\right.$ for $30 \mathrm{~min}$.), to the third $5 \mathrm{ml}$. of active $\mathrm{RDE}$ and to the fourth $5 \mathrm{ml}$. of heatinactivated $\mathrm{RDE}\left(100^{\circ}\right.$ for $15 \mathrm{~min}$.). Hanks solution $(5 \mathrm{ml}$.) was added to portions 5 and 6. Portions 1-5 were incubated overnight at $37^{\circ}$ and portion 6 was held at $4^{\circ}$. Two control mixtures of CBO virus and Hanks solution were similarly allowed to stand at room temperature for $1 \mathrm{hr}$. They were then diluted with $5 \mathrm{ml}$. Hanks solution and one was incubated overnight at $37^{\circ}$ and one held at $4^{\circ}$. On the following morning RDE, where present, was inactivated by the addition of sodium citrate, and all the solutions were diluted to $10 \mathrm{ml}$. and assayed for $\mathrm{HI}$ activity with heated influenza B virus (Lee) and for active CBO virus. CBO virus was only slightly inactivated during incubation at $37^{\circ}$ and sufficient inhibitor was supplied in the rabbit serum to inactivate the $\mathrm{CBO}$ virus completely. No reactivation of virus occurred as a result of the incubation or dilution, but active CBO virus was released from combination with the neutralizing agent of rabbit serum by RDE and active influenza $B$ virus (Lee), both of which destroyed the $\mathrm{HI}$ activity of the serum against 
heated influenza $B$ virus (Lee) ('Table 7). The recovery of active virus was about $50 \%$ when RDE was used, about $10 \%$ with active influenza $B$ virus (Lee).

\begin{tabular}{|c|c|c|}
\hline $\begin{array}{l}\text { CBO virus }+ \text { inhibitor complex } \\
\text { treated with }\end{array}$ & $\begin{array}{c}\text { Titre of } \\
\text { CBO virus } \\
\text { p.f.u./ml. }\end{array}$ & $\begin{array}{c}\text { Inhibitor } \\
\text { content } \\
\text { against 4 AD } \\
\text { of Lee B } \\
\text { indicator } \\
\text { virus }\end{array}$ \\
\hline $\begin{array}{l}\text { (1) Active Lee B* } \\
\text { (2) Heated Lee B } \\
\text { (3) RDE } \\
\text { (4) Heated RDE } \\
\text { (5) Hanks at } 4^{\circ} \\
\text { (6) Hanks at } 37^{\circ}\end{array}$ & $\begin{array}{c}1.3 \times 10^{3} \\
\mathrm{Nil} \\
6 \cdot 7 \times 10^{3} \\
\mathrm{Nil} \\
\mathrm{Nil} \\
\mathrm{Nil}\end{array}$ & $\begin{array}{r}<10 \\
40 \\
<10 \\
40 \\
40 \\
40\end{array}$ \\
\hline $\begin{array}{l}\text { (7) CBO virus control at } 4^{\circ} \\
\text { (8) } \mathrm{CBO} \text { virus control at } 37^{\circ}\end{array}$ & $\begin{array}{r}34 \times 10^{3} \\
12.5 \times 10^{3}\end{array}$ & 二 \\
\hline
\end{tabular}

* Active Lee B did not produce plaques on agar suspension cultures of chick embryo cells.

\section{DISCUSSION}

The infectivity of the Van den Ende strain of CBO virus, demonstrable by the formation of plaques in chick embryo cell monolayer cultures, cytopathic effect in chick tissue cultures or mortality in chick embryos, appeared to be almost completely neutralized by normal rabbit sera heated to destroy inhibitors of the heat labile type. Such sera had no effect upon the infectivity of all the other viruses tested in this investigation with the exception of one strain of enteric cytopathogenic bovine orphan virus (ECBO).

In the normal sera examined, the species distribution of the $\mathrm{CBO}$ virus inhibitor differed considerably from that of the Francis type of inhibitor of influenza $B$ (Lee) indicator virus. This difference was most marked in rabbit and ferret serum. This lack of parallelism in inhibitory activity has been demonstrated by Ananthanarayan \& Paniker (1960) who showed that among the myxoviruses considerable variations occurred in the susceptibilities of different strains to the same or similar inhibitors. Conversely, it may be true that haemagglutination inhibition is not due to one substance but to a number of serum mucoproteins of varied activity towards different strains of virus.

The electrophoretic behaviour of the $\alpha$ inhibitor in animal sera was examined by Tyrrell (1954), Harboe, Raenaas \& Oppedal (1958) and Levy, Norman \& Wagner (1959) and when allowance is made for different techniques, their results indicate that the active substances have mobilities approximating to that of the $\alpha$ globulin fraction. The CBO inhibitor in normal rabbit serum has a similar mobility. The peaks of inhibitory activity for haemagglutination by Lee $\mathrm{B}$ virus and for the infectivity of $\mathrm{CBO}$ virus were coincident.

Confirmation of the association of the inhibitor with the globulins was obtained when sera were half saturated with ammonium sulphate. It is not clear whether the precipitation of the inhibitor at $\mathrm{pH} \mathbf{5 \cdot 2}$ is a specific property of the substance or whether it was due to adsorption to other serum constituents precipitated at this 
pH value. It provided, however, a further method of eliminating albumin and distinguishing it from immune $\gamma$ globulin. In addition, the inhibitory activity was shown to be independent of properdin.

The heat stability and the sensitivity of the inhibitor to periodate and trypsin suggest that it is a mucoprotein and the presence of sialic acid may be inferred from its sensitivity to neuraminidase. Mucoproteins from other sources having high haemagglutination inhibition activity for the influenza $B$ (Lee) indicator virus were without effect upon CBO virus infectivity, suggesting that CBO virus is more restricted than some of the influenza viruses in the range of mucoproteins with which it can combine.

The experiments with the virus + inhibitor complex show that, in contrast to active influenza virus, the complex is not dissociable by time or temperature, nor is it dissociated on simple dilution. The adsorption of CBO virus to certain red cells which are not agglutinated (Kipps et al. 1961), and to the inhibitory substance in normal animal sera, can be reversed by RDE and active influenza $B$ virus (Lee), implying that while the $\mathrm{CBO}$ virus combines with inhibitor in a manner similar to the influenza viruses it lacks the necessary enzyme for its own elution.

\section{REFERENCES}

Ananthanarayan, R. \& Paniker, C. K. J. (1960). Non-specific inhibitors of influenza viruses in normal sera. Bull. World Hlth. Org. 22, 409.

BurNET, F. M. (1948). The initiation of cellular infection by influenza and related viruses. Lancet, $i, \gamma$.

Cooper, P. D. (1955). A method for producing plaques in agar suspensions of animal cells. Virology, 1, 397.

Harboe, A., Raenaas, R. \& Oppedal, M. (1958). Studies on Francis inhibitor of influenza virus haemagglutination in rabbit serum fractions obtained by electrophoresis on starchgrain. Acta path. microbiol. scand. 44, 92.

Kipps, A., Turner, G. S. \& Polson, A. (1961). Some properties of a cytopathogenic bovine orphan virus (Van den Ende strain). J. gen. Microbiol. 26, 405.

Levy, A. H., Norman, P. S. \& WAGner, R. R. (1959). Electrophoresis of serum inhibitors of influenza viruses. Fed. Proc. 18, 580.

Peterson, E. A. \& Sober, H. A. (1956). Chromatography of proteins. I. Cellulose ion exchange adsorbents. J. Amer. chem. Soc. 78, 751.

Polson, A. (1952). An improved electrophoresis cell for the analysis of several sera simultaneously. Nature, Lond. 170, 628.

Polson, A., Joubert, F. J. \& Haig, D. A. (1946). An electrophoretic examination of cobra venoms. Biochem. J. 40, 265.

Pillemer, L., Blum, L., Lepow, I. H., Ross, O. A., Todn, E. W. \& Wardlow, A. C. (1954). Demonstration and isolation of a new protein, properdin and its role in immune phenomena. Science, 120, 279.

Sugihara, T. F., McDonell, L. R., Knight, C. A. \& Feeney, R. E. (1955). Virus antihaemagglutinin activities of avian egg components. Biochim. biophys. Acta, 16, 404.

Svensson, H. \& Valmet, E. (1955). Density gradient electrophoresis. A new method of separating electrically charged compounds. Science Tools, $2,11$.

TyrReLl, D. A. J. (1954). Separation of inhibitors of haemagglutination and specific antibodies for influenza viruses by starch zone electrophoresis. J. Immunol. 72, 494.

Zhdanov, V. M., Hamburg, V. P. \& Svet-Moldavsky, G. J. (1959). Antigenicity of the inhibitor of influenza virus strain A/Asia/57. J. Immunol. 82, 9. 